\title{
ASPECTOS DA CULPABILIDADE NO DIREITO PENAL
}

\author{
ALCIDES MUNHOZ NETTO \\ Livre Docente de Direito Penal
}

SUMÁRIO: 1 - A culpabilidade na estrutura do crime; 2 - Evolução histórica; 3 - Concepção psicológica e concepção normativa de culpabilidade; 4 - Censurabilidade e liberdade de vontade; 5 - Culpabilidade pelo ato isolado; 6 - Elementos da culpabilidade; 7 - O princípio do nulà poena sine culpa e a responsabilidade objetiva; 8 - A tendência atual do direito penal no setor da culpabilidade.

1. Para a existência do crime não basta a adequada relação de divergência objetiva entre a ação e a ordem jurídica, nem é suficiente $o$ nexo de causalidade física, que liga a conduta ao resultado. Necessário se faz, ainda, que a ação se apresente psicològicamente relacionada ao autor e o faça objeto de reprovação pessoal, por não haver omitido a ação antijurídica, apesar de haver podido omitíla. Neste vínculo psicológico e nesta reprovabilidade é que reside a culpabilidade ou culpa lacło sensu, assim qualificada para que não se confunda com a culpa em sentido estrito, ou seja, a produção de um dano por imprudência ou negligência. Ao contrário do que sucede com a lingua alemã, que, com maior riqueza, possui o vocábulo Shuld para denominar a culpabilidade em sentido amplo e o têrmo Fahrlassigkeit para designar a culpa stricto sensu, os idiomas de origem latina só dispõem ḍas palavras culpabilidade e culpa, para indicar indistintamente as duas situações. Considerada no primeiro significado, é que a culpabilidade se apresenta como elemento estrutural do delito, ao lado da tipicidade e da antijuridicidade.

$E^{\prime}$ ela, precisamente por refletir a base humana em que o crime tem as suas raízes, o mais delicado dos componentes do ilícito penal. Enquanto a tipicidade exaure-se, via de regra, no terreno descritivo e a antijuridicidade na valoração objetiva, a culpabilidade realiza a individualização da responsabilidade penal, que é um dos princípios basilares do moderno direito punitivo.

Daí a observação de Asúa de "que ao chegar à culpabilidade 
é quando o intérprete há de extremar a finura de suas armas, para que fique o mais afastado possível, no processo de subsunção, o juízo de reprovação pelo ato concreto praticado" (La Ley y El Delito, pág. 379).

Não é de estranhar, portanto, que a culpabilidade constitua um dos capítulos fundamentais da teoria do delito, dando ensejo a uma enorme produção científica, principalmente entre os alemães, à cuja técnica se deve a construção dêsse moderno instituto, tal como hoje é concedido. HAFTER chega ḿesmo a afirmar, que "o problema da culpabilidade é o problema mesmo do direito de castigar".

2. Nem sempre, entretanto, se emprestou tal importância ao conteúdo moral do delito. Em seus primórdios, caracterizou-se o Direito Penal por sua rude objetividade. A pena sacral satisfazia-se com o aspecto objetivo da infração e recaía sôbre atos praticados ou não em condições de imputabilidade. Durante todo o período jurídico privado o decisivo era o resultado, como medida para a compositio ou para a vingança de sangue.

Entre os gregos acreditava-se que o destino castigava às cegas culpados e inocentes e pela religião hebraica, pararela à teocracia política, a pena ultrapassava a pessoa do criminoso, estendendo-se aos seus descendentes até a 7 a. geração.

Não possuiam os povos primitivos noção de culpabilidade e de personalidade da pena.

Sôbre o Direito Romano dos primeiros tempos, não há perfeito acôrdo quanto ao valor que atribuia ao aspecto subjetivo do crime. FERRINI não admite sequer, que, "no estado originário, haja existido uma fase material objetiva. Sustenta que a distinção entre homicídio voluntário e casual remonta além de todo confim histórico, transcendendo a fase ária. Não admite nem mesmo, como fato indiscutível, "que a concepção objetiva haja preponderado na esfera dos delitos privados" (D. Penal Romano, págs.•77 e 78). Já MONSEM é de parecer, que o primitivo Direito Romano "desconheceu o princípio, introduzido mais tarde, de que o conceito de delito requer a existência de uma vontade contrária à lei, na pessoa capaz de agir". (Derecho Penal Romano, pág. 94).

O que se pode afirmar, é que a Lei das XII Tábuas, codificada aproximadamente no ano $450 \mathrm{~A}$. C., em fins do período quiritário e iá na era republicana, sentenciava que "si quis liberum hominem dolo sciens morti druit, parricida esto" o que vem demonstrar que a acurada mentalidade jurídica dos romanos bem cedo se voltou para o nexo subjetivo que deve existir entre o autor e o fato punível. E daí há de ter se originado o princípio, vigorante depois, de que tôdas as ações, castigadas com pena pública, deveriam revestirse de dolo.

Já no Direito germânico, de espírito mais objetivo, a fase pré- 
subjetiva prolongou-se mais. A reparação privada provinha do dano. O Wergeld era pago, a título de ressarcimento, sem que se fizesse qualquer distinção entre fatos voluntários e involuntários. Como observa LAERTES MUNHOZ, "a rude consciência jurídica dessa época não alcançava compreender como um fato danoso qualquer pudesse ficar impune" (Da Causalidade subjetiva no Código Penal brasileiro, pág. 7). Só em relação ao Fredus, forma primitiva de pena pública, é que o pagamento se subordinava à intencionalidade do dano cometido.

O cristianismo trouxe grande contribuição ao pensamento da culpabilidade, como requisito do crime. Valorizando a intimidade da consciência, estabe!eceu o princípio de que onde não há vontade não há pecado, norma em que veio se alicerçar o direito eclesiástico, o qual, além disso, começou a desenvolver a teoria da culpa em sentido estrito, diversificando a pena, conforme o dano fôsse determinado pela vontade ou sòmente pela imprudência ou negligência.

Mas, ao lado desta contribuição inestimável, o direito canônico veio a adotar o pensamento da versari in re illicita que, no fundo, representava a persistência da responsabilidade objetiva. Entendiase por culpabilidade nem só o dolo e a culpa, como a produção de um resultado delituoso involuntário e fortuito, por quem se dispunha a realizar algo não permitido: "versanti in re illiciła imputatur omnia que sequuntur ex delicto".

Consequência dêste princípio foi a teoria do dolus indirectus, de larga duração, e que entendia dever ser atribuído à culpabilidade - resultado só indiretamente querido. Sustentava-se que, se a ação planejada revelasse tendência a estender-se, com certa probabilidade, ao resultado verificado, êste seria doloso, apesar de não ter sido querido nem consentido. Tal pensamento, diz MEZGER, aparece unido à exigência de que a ação planejada tenha caráter delituoso, vale dizer, representa em si mesma um versari in re illicita. (Tratado de Derecho Penal, tomo II, § 34, pág. 26).

Hoje, superadas as teorias do versari in re illicita e do dolus indirectus, caminha o Direito Penal para o banimento de todos os casos de responsabilidade objetiva, isto é, da responsabilidade, como acentúa CAVALLO, por um evento atribuível ao agente pelo simples nexo de causalidade material, excluída tôda a contribuição do elemento espiritual, cognoscitivo ou valorativo". (La Responsabilitá Obbiettiva nel Diritto Penale, 1937, pág. 538).

3. Na moderna dogmática penal, prevalece, contudo, a princípio, a concepção bi-partida de crime, que separava nítidamente o interno do externo, o subjetivo do objetivo. Enquanto o objetivo externo concernia à anti-juridicidade, devia pertencer a culpabilidade ao subjetivo interno. Era ela encarada como a simples relação psíquica entre o autor e o resultado, e, pois como um fato de natureza puramente psicológico. Denominou-se a esta doutrina teoria psi- 
cológica da culpabilidade, ou simplesmente psicologismo. Tôda a culpabilidade esgotar-se-ia no processo intelectual volitivo que se desenvolve no autor, no momento do delito e em relação a êste. (RIGARRO C. NUÑEZ, La Culpabilidad en el Codigo Penal, pág. 3).

Divisava-se na culpabilidade, portanto, apenas o que ela possui de mais aparente, ou seja, o fator psicológico, que faz do agente o autor do fato incriminado. E o estudo dêsse importante elemento do delito, cingia-se ao estudo das formas de vinculação entre autor e ato, que são o dolo e a culpa.

A concepção psicológica da culpabilidade aparece em CARRARA, para quem a culpabilidade era a fôrça moral subjetiva do delito, cujo conteúdo psicológico residiria na intenção, que podia ser direta, no caso de dolo, e indireta, no caso de culpa. (Programa de D. Criminal, $\S \S 59,66)$.

Mas esta concepção era evidentemente insuficiente para uma exata conceituação da culpabilidade. Impugnava-se a sua aplicação aos casos de culpa inconsciente, em que não se caracterizaria aquela relação psíquica entre a vontade e o evento. Por outro lado, objetava-se que ela se detinha em um juízo sôbre a ação, como pertencente ao réu, sem explicar porque êste devia responder pela ação.

Nos começos dêste século, operou-se verdadeira revolução no campo da culpabilidade, quando, no dizer de BETTIOL, a doutrina se apercebeu que culpabilidade não é tanto uma vontade referente a um fato, que não se devia praticar, quanto uma vontade que não deveria ter existido. (Diritto Penale, pág. 260).

Foi então, que, contrapondo-se à concepção psicológica, surgiu a concepção normativa de culpabilidade, fruto do apuramento dogmático do Direito Penal na Alemanha.

A concepção normativa tem por base a filosofia dos valores de WINDELBAND e RICKERT e proclama que a base da culpabilidade é um juízo de valor. Foi FRANK, em 1907, quem desenvolveu estas novas idéias, ao observar que o momento psicológico, expresso no dolo e na culpa, não esgota todo o conteúdo da culpabilidade. Esta é sobretudo reprovabilidade e seu conceito deve ser construído, nem só com o dolo e a culpa, como também com a imputabilidade e a normalidade das circunstâncias concomitantes ao fato punivel. Como diz RICARDO NUÑEZ, a culpabilidade já não é um puro fato psicológico, senão um processo dêsse caráter, porém anormal, por ser atribuível a uma motivação reprovável do autor. O processo de motivação que conduziu o autor a uma situação psicológica de culpabilidade (dolo ou culpa) é reprovável se as circunstâncias internas e externas, concomitantes a sua ação delituosa, demonstram que the era exigível comportamento psíquico distinto do observado. Assim se explica, como, em virtude dessa teoria, aparecem, dominando o 
campo da culpabilidade, os conceitos de reprovabilidade e de seu pressuposto, a exigibilidade. (La Culpabilidad, pág. 5).

A concepção normativa empolgou, desde logo, a doutrina alemã, figurando entre os seus seguidores GOLDSGHMIDT, MAX ERNEST MAYER e MEZGER. E' hoje a doutrina dominante nesse país, seguida inclusive pelos partidários da moderna teoria da ação finalista, embora com pequenas modificações. Na ltália e nos países latinos em geral, o normativismo igualmente tem encontrado crescente aceitação.

A doutrina normativa, no entanto, está longe de haver atingido um ponto de eśtratificação, o que é demonstrado pelas divergências existentes entre os seus partidários. Enquanto na primitiva concepção, o juízo de reprovabilidade tinha por objeto a violação consciente e livre de uma norma de direito, em GOLDSCHMIDT êle decorreria da infração a uma norma de dever. Entendia o exímio professor da Universidade de Berlim que "ao lado da norma de direito, que exige determinada conduta externa, há uma norma, não declarada expressamente, que impõe ao indivíduo o dever de conformar a sua conduta interna de maneira necessária a poder corresponder às exigências que o ordenamento jurídico estabelece, a respeito de sua conduta externa (apud. E. MEZGER, D. Penal, t. II, pág. 15). Conforme assinala RICARDO NUÑEZ, GOLDSCHMIDT liga a sua teoria à metafísica kantiana e diz que é ela o resultado da aplicação do seguinte pensamento de KANT à esfera jurídica: a tôda legislação pertencem duas partes: uma é a que prescreve a ação que se deve executar como objetivamente necessária, isto é, que faz da ação um dever; a outra é a parte que liga subjetivamente a causa determinante do arbítrio, com a representação da lei, vale dizer, que faz do dever o motivo. Aplicando êste pensamento ao direito positivo, diz GOLDSCHMIDT, resulta que a todo o imperativo jurídico é imanente uma norma de motivação, que exige que o indivíduo determine-se pela representação dêste imperativo. (Bosquejo de La Culpabilidad, $X X X I)$.

Admite ainda GOLDSCHMIDT uma independência entre a nor. ma de direito e a norma de dever.

MEZGER não concorda com essas idéias e, em crítica inteiramente procedente, observa que sem uma norma valorativa não existe nenhuma norma de determinação independente. Aquela é pressu. posto lógico desta, faltando, portanto à norma de dever a independência interna frente ao injusto. Por outro lado, o penalista e filósofo de Munich põe em evidência a inaplicabilidade do exemplo da tentativa ao pensamento de GOLDSCHMIDT, uma vez que, pela dominante teoria objetiva do crime tentado, a sua antijuridicidade é deduzida da execução típica e da colocação do bem jurídico em pe. rigo (D. Penal, †. II, pág. 15).

Mais recentemente, HANS WELZEL, com a sua teoria finalista 
da ação, também subverte a originária construção do normativismo na culpabilidade. O dolo e a culpa, para êle, não integram a culpabilidade, como em FRANK. Pertencem à ação e com ela devem ser examinados, como fatôres que a determinam finalísticamente. A culpabilidade seria apenas a reprovabilidade da formação da vontade ilícita (Derecho Penal, págs. 45 e 152).

O pensamento da ação finalista, com suas consequências no terreno da culpabilidade, não vem encontrando inteira aceitação nem mesmo entre os alemães. Arğui-se que ela, além de revolucionar tôda a teoria do delito, esvasia a culpabilidade de todo o conteúdo psicológico. Há, entretanto, um certo exagêro nesta segunda crítica, pois que, embora deslocando o dolo e a culpa para a estrutura da ação, a teoria finalista não deixa de levá-los em conta também no exame da culpabilidade, como objeto de sua valoração. Segundo WELZEL, " na teoria da culpabilidade, só se trata de seu conteúdo, enquanto que o seu objeto (dolo e culpa) já terá sido averiguado na teoria da ação e do injusto" (ob. cit. pág. 150). Mas, como o juízo de reprovabilidade é feito tendo em vista uma vontade antijurídica, que não se deveria ter formado, é evidente que o dolo e a culpa não se desvinculam da culpabilidade, nem mesmo na teoria finalista.

E nem seria possível que tal ocorresse, pois não é curial cogitar de culpabilidade com abstração do dolo e da culpa, isto é, sem levar em conta o conteúdo da vontade, que vincula o indivíduo ao ato.

Da mesma forma, porém, que não se pode retirar da culpabilidade o seu fator psicológico, também não é admissível olvidar que a incriminação da vontade só se justifica tendo-se em vista a sua reprovabilidade. Sendo a pena o malum passionis ob malum actionis, deve ela ser aplicada a quem praticou o ato ilícito de forma reprovável. A ordem jurídica impõe uma obediência às suas normas, de sorte que se alguém, tendo ou podendo ter a consciência de que falta a tal dever, de conformidade com a qual podiå agir, atua de maneira contrária ao direito, sua vontade é ilícita. Não deveria tê-la tido, daí a reprovação de que se faz objeto. (A. BRUNO, ob. cit. t. 2, pág. 412).

Pode-se, assim, concluir com MAGALHÃES NORONHA, que a culpabilidade é psicológico-normativa e que as duas concepcões não se repudiam, mas se completam, operando $\mathrm{em}$ setores diferentes: enquanto a psicológica vincula estritamente o indivíduo ao ato, a normativa refere-se à ilicitude dêste proceder. (Direito Penal, vol. 1, pág. 132).

Êste conteúdo normativo da culpabilidade tem sido, no entanto, impugnado por alguns. Diz-se ser inadmissível que a culpabilidade de um homem não deva residir em sua própria cabeça mas na cabeça de outrem. Tal a crítica feita por ROSENFELD, que, todavia, não procede. $E^{\prime}$ certo que para ser culpável o agente deve ter 
a consciência ou a possibilidade da consciência da antijurídicidade de seu ato. Só assim sua vontade pode ser censurável. E êste é um dado que hoje integra a culpabilidade. Mas não se pode pretender que o agente censure-se a si próprio, o que raramente ocorre. A reprovação é feita pela sociedade, pelo Estado que é a sua organização jurídica, através do registrado, a quem o Estado delegou a função punitiva. Embora o juízo de culpabilidade ligue-se a uma determinada situação de fato, que reside no agente, não se pode duvidar, como nota MEZGER, que esta situação deva ser valorizada e conside. rada como um processo reprovável para o agente. (ob. cit., t. 2, pág. 4).

Mais profunda é a crítica que SEBASTIAN SOLER dirige à exigência de reprovabilidade, que o normativismo introduz. Entende êle, que, com tal ćritério, a própria antijuridicidade objetiva seria elemento da culpabilidade, pois aquela é precisamente, no seu entender, a circunstância em que se baseia o juízo de reprovação, já que só os fatos antijurídicos podem ser reprovados. A reprovação seria a reação social ou jurídica, determinada pelo delito cometido, com todos os seus elementos. (Derecho Penal Argentino, vol. II, pág. 13). E' preciso, todavia, distinguir a reprovação decorrente da antijuridicidade, da reprovação que integra a culpabilidade: alí reprovase o fato, aqui o agente. Colocada a questão nestes têrmos, antijuridicidade e culpabilidade ficam perfeitamente diferenciadas. O juízo de desvalor objetivo que se encerra na antijuridicidade, não importa ainda na censurabilidade da conduta culpável, até porque o agente pode praticar uma ação contrária ao direito e, não obstante, não incidir em reprovação pessoal, o que sucede quando outro comportamento não se the poderia exigir.

E a maior vantagem introduzida pelo normativismo, é precisamente, como assevera ASÚA, a de permitir a construção de uma causa geral de exclusão da culpabilidade, denominada inexibilidade de outra conduta (ob. cit., pág. 382). A conduta só se considera culpável quando outro comportamento não se poderia exigir do agente. Exclui-se a reprovação e, portanto, a culpabilidade se ocorrem circunstâncias, em face das quais não se pode exigir de quem atua um comportamento ajustado ao direito (G. DELITALA, II fato nella Teoria Genera!é del Reato pág. 85).

4. Mas o problema da exibilidade ou não de comportamento conforme ao direito não importaria em admitir a liberdade de vontade, revivendo assim o velho debate, que há algum tempo empolgou o Direito Penal, entre livre arbítrio e determinismo.

Sabe-se que a tese, de que a base da culpabilidade repousava no livre arbítrio, permaneceu pràticamente incontestada até o século passado. Desde a Idade Média, por influência dos teólogos, afirmava-se o princípio da responsabilidade moral, baseada na faculdade onímoda da vontade. Na escola clássica, êste pensamento ad- 
quiriu os caracteres de um axioma, servindo de fundamento à tôda construção científica do Direito Penal. Segundo CARRARA, a teoria da imputação contemplaria os delitos em suas puras relações com - agente, e êste, em suas relações com a lei moral, consoante os princípios do livre arbítrio e da responsabilidade humana, que a êle, CARRARA, se afiguravam como imutáveis. E afirmava: "Eu não me preocupo com discussões filosóficas; pressuponho aceita a doutrina do livre arbítrio e da imputabilidade moral do homem e sôbre esta base edificada a ciência criminal, que mal se constituiria sem aquela (Programa, § I e nota 2).

Contrapondo-se a essas idéias, nos começos do século XIX, surge a escola filosófica dos deterministas, que sustenta ser o livre arbítrio mera ilusão, decorrente de um desconhecimento absoluto dos fatôres que intervêm no processo de nossas resoluções. A vontade não seria livre, mas resultante de um complexo de fatôres. No campo psicológico existiria a mesma lei de causalidade natural, de que todo o efeito é consequência necessária e inevitável de um complexo de causas. Todo homem tem a sua personalidade física e psíquica que se manifestaria em todos os seus atos e que seria determinada fundamentalmente pela herança e desenvolvida segundo o ambiente.

Modernamente, entende-se que esta controvérsia não tem interêsse para o Direito Penal, sendo do domínio da religião ou da moral. Tanto os penalistas italianos, ALIMENA e MANZINI, quanto os alemães, FRANK, KOHLER, MEZGER, consideram bizantina a questão e proclamam que ao Direito Penal, construído de realidades tangíveis, basta que a vontade seja livre, no sentido de não coacta. Realmente devemos admitir como possível, ao aủtor, vencer os impulsos contrários ao direito, resultantes de sua personalidade, formação, ambiente e outros fatôres, bem como reconhecer que o homem imputável, com capacidade de entendimento e auto determinação, pode atuar de modo adequado ao direito, sem que isto importe em aceitar uma liberdade de escolha entre o bem e o mal, entre valor e desvalor, como pretendiam os indeterministas. Nestes têrmos é que a vontade é livre, servindo de base à culpabilidade. Esta se apresntaria, no dizer de WELZEL, como a falta de auto-determinação adequada ao sentido, em um sujeito capaz desta determinação de acôrdo com os entendido. Não é uma decisão adequada ao sentido a favor do mal, senão o permanecer dependente e deixar-se levar por impulsos contrários ao valor". (ob. cit. pág. 162).

Ora, esta correta posição em nada é preịudicada pelo requisito da exigibilidade de conduta diversa, pois que êste pressupõe, precisamente, apenas a faculdade, que se reconhece no homem normal, de resistir aos seus próprios impulsos, conformando a sua conduta às exigências do direito. Só quando não o faça é que incidirá em reprovação pessoal.

5. O juízo de reprovação é feito tendo-se em vista a prática, 
pelo agente, de um fato punível. E como todo o injusto é fato isolado, também a culpabilidade diz respeito a um ato isolado, pressupondo o seu exame a antijuridicidade e a tipicidade da conduta. Sem o antecedente de um injusto típico realizado, não há falar em culpabilidade.

Tôdas as tentativas de desligar a culpabilidade do fato isolado, para vinculá-la à personalidade, ao caráter, ou ao modo de vida do agente, além de não se harmonizarem com o direito positivo, revelam-se insuficientes e perigosas.

A teoria sintomática, faz da culpabilidade o eixo da teoria do delito. O crime praticado apresentar-se-ia apenas como sintoma, como critério de reconhecimento da culpabilidade. A personalidade do agente, revelada através do delito, é que seria o fundamento da pena.

Segundo TESAR, o desenvolvimento histórico-dogmático da doutrina dos fatôres condicionantes da gravidade da infração demonstra a possibilidade de dois tipos de avaliação da conduta criminosa: o primeiro que julga o comportamento na média do dano efetivamente causado no mundo externo; o outro, ao contrário, que avalia o fato pelo que êste possa revelar do réu. O transcorrer dos tempos e o progresso científico teriam conduzido a uma crescente afirmação dêste segundo princípio, pelo qual o comportamento externo tem valor sòmente como sintoma de um determinado substrato psicológico. (apud M. GALLO, II Concetto Unitário di Colpevolezza, pág. 105).

Ora, tal orientação colide com o princípio dominante de que a pena há de se ligar ao efeito típico da ação, ou seja, ao resultado e, com isto, ao injusto. A culpabilidade é um pressuposto da sanção penal, mas não o seu único fundamento.

Também VON LISZT, na vigésima edição de seu Lehrbuch, obscurece a consideração da culpabilidade pelo ato isolado, ao considerar, como objeto do juízo de culpabilidade, o caráter do autor. Culpabilidade seria a relação subjetiva entre o fato e o autor, a qual só poderia ser de índole psicológica. Todavia, a natureza da ação seria deduzida do conteúdo material do conceito de culpabilidade, que residiria no caráter anti-social do autor, revelado pelo ato cometido (Tratado de Derecho Penal, trad. de L. J. ASÚA, vol. II, § 36, n. I).

Estas idéias serviram de base á outra doutrina semelhante, surgida mais tarde, também na Alemanha. Trata-se da chamada teoria da culpabilidade pela conduta de vida, segundo a qual não é o ato, ou série de atos, que fundamenta a reprovação, mas sim o estilo de vida (Lebensfuhrungsschuld). O sujeito dirigiu sua vida contra o direito, quando podia ter feito o contrário e, por isto, é reprovável. KOLRAUSCH, partidário desta orientação, conceitua mesmo a culpabilidade como "uma contradição entre as leis da vida do indivíduo e as normas do mundo circundante". (apud. E. MEZGER, ob. cit. r. 2, pág. 19). 
Ambas as concepções igualmente conflitam com o pensamento vitorioso, de que a culpabilidade é uma propriedade da ação concreta e típica, surgindo com o ato sôbre o qual o juiz deve aplicar a pena. E, muito embora não prescindam de todo do injusto, pois que nelas há sempre um fato a que se refere imediatamente o juízo de culpabilidade, apresentam o grave risco de conduzir ao abandono do fundamental princípio da reserva legal, o que também ocorre com a teoria sintomática, porque origem em fundamento essencial da reprovação e da pena a personalidade, o caráter e o modo de vida do agente. Daí. a crítica veemente que JUAN DEL ROSAL opõe à última das doutrinas, de que só "uma concepção política do direito, que intentou assenhorar-se da pessoa, pôde dar oportunidade a esta doutrina da culpabilidade pelo modo de ser da pessoa, doutrina que não só opera à base de ficções, como disse H. Mayer, como é também contrária à pura tradição do pensamento ocidental". (La Personalidad del Dellincuente en La Téenica Penal, 1953, pág. 79).

WILHELM SAUER, de formação filosófico-criminológica, além de procurar ligar a sua teoria sôbre a culpabilidade à ética, não limita o objeto da culpabilidade ao puro ato concreto. Considera como objeto da culpabilidade a tendência de fôrça e de valor de um homem, especialmente seu querer. $O$ ato culpável seria uma projeção, arrancada do interior do ser humano, que adquire forma particular na contradição com o preceito vigente. Pela sua teoria criminalística da criação, "o ponto nevrálgico e etiológico reside no ato de criação da própria vontade do autor, não na disposição do mundo circundante, e - juízo de culpabilidade incidiria sôbre tôda a fase subjetiva do iter criminis, abrangendo o exame do primeiro impulso criminoso, a luta entre motivos e contra-motivos, a resolução e a vontade de agir e o querer em atuação, em que se apresentaria o dolo ou a culpa. (Derecho Penal, Parte General, § 19).

Perante o direito positivo, no entanto, êstes fatôres atinentes ao desenvolvimento da decisão delituosa se de um modo mediato são considerados.

Servem como elementos para a fixação da pena, com o exame da intensidade do dolo ou do grau da culpa, pesquisa que envolve indagações sôbre todo o processo de formação da vontade. Não são, assim, objetos do juízo de culpabilidade, mas de sua gradação.

De qualquer forma, tôdas essas idéias tiveram o mérito de cha. mar a atenção para o importante papel, que o caráter, a personalidade e os antecedentes do autor devem desempenhar na fixação da pena. Todavia, como nota MARCELLO GALLO, invocando BELLAVISTA, quando isto ocorre, vale dizer, no momento da aplicação judiciária da pena, lógica e cronológicamente, pressupõe-se já caracterizado o crime e a culpabilidade que é um de seus elementos. (ob. cit. pág. 108). 
6. De tôdas as considerações que até aqui fizemos, ressalta que a culpabilidade é o iuízo de reprovação, incidente sôbre aquêle, que, com dolo ou culpa, pratica um fato que sabia ou podia saber antijurídico, e do qual poderia abster-se.

Dêste conceito é fácil deduzir que são elementos da culpabilidade a imputabilidade, o nexo psicológico entre o autor e o ato e a ausência de causas capazes de excluir a possibilidade de consciência do fato e de sua ilicitude ou a liberdade de vontade.

A imputabilidade, entendida como a capacidade de conhecer o fato e sua antijuridicidade e de determinar a vontade de acôrdo com tal entendimento, é por alguns considerada como mero pressuposto da culpabilidade, Tal é a posição que, entre nós assume NELSON HUNGRIA (Comentários ao Código Penal, vol. I, n. ${ }^{\circ} 101$ ), seguindo assim KOLRAUSCH, GERLAND, LISZT, SCHMIDT e BELING. Mas, como o que é pressuposto, é, também, conforme MEZGER, de modo necessário, característica (ob. cit., †. 2, pág. 42), há apenas uma aparente divergência entre êstes e os que situam a imputabilidade como parte integrante da culpabilidade.

O indubitável é que, para que o agente possa formar uma vontade contrária à norma, em lugar da vontade a ela adequada, é necessário, ante's de tudo, que seja capaz de perceber o sentido injusto de seu ato e ainda que possa auto-determinar-se por tal entendimento. Com efeito, não é sabível censurar a vontade anti-jurídica em quem, por determinada situação mental, não alcance o caráter anjurídico do fato ou seja incapaz de dirigir-se de acôrdo com êsse conhecimento. A capacidade de imputação apresenta-se, pois, como a própria capacidade de culpa.

- nexo psicológico entre o agente e o ato é constituído pelo dolo e pela culpa em sentido estrito. O dolo, como a vontade e aquiescência em produzir o résultado antijurídico e a culpa, como a omissão das cautelas impostas pela previsibilidade de uma lesão jurídica, são as formas pelas quais se apresenta a ação censurável do autor. E' óbvio que um estudo dos diversos aspectos dessas duas formas dé culpabilidade transcende o âmbito restrito dêste trabalho, em que procuramos focalizar princípios gerais da culpabilidade, sem descer ao estudo minucioso de seus componentes.

Finalmente, a ausência de especiais causas de exclusão da culpabilidade', apresenta-se como o fator negativo da culpabilidade. Já foi observado que a.censurabilidade da conduta demanda a consciência ou a possibilidade da consciência da ilicitude do fato, de modo a que a norma possa funcionar como motivo determinante da vontade. E vimos ainda, que para ser reprovável é necessário, ademais, que o fato ocorra em situação que seja lícito exigir do agente comportamento diverso. Portanto, qualquer causa que impossibilite o: conhecimento do fato e da sua ilicitude, ou que anule a liberdade de vontade, excluirá a culpabilidade. Na primeira hipótese figuram 
- êrro de fato, as chamadas dirimentes putativas e a obediência hierárquica, reconhecidas pela legislação como excludentes da culpabilidade. E deveria estar incluído entre elas o êrro de direito essencial e escusável, ao qual o nosso Código, por conveniências de política criminal, não emprestou tal efeito. Como pondera BASILEU GAR$\mathrm{ClA}$, "não há hipótese mais incontestável de ausência de percepção da ilicitude do fato, que o desconhecimento de estar êle previsto na lei repressiva". (Instituições de Direito Penal, pág. 254).

Os fatôres que excluem a liberdade de vontade cifram-se nos casos de inexigibilidade de outra conduta, de que são exemplos típicos a coação irresistível e o estado de necessidade, êste elevado por nossa legislação a causa de exclusão da antijuridicidade.

Debate-se, contudo, se a inexigibilidade de outra conduta só pode funcionar como fundamento das causas de exclusão da culpa previstas em lei, ou se pode constituir uma causa supra legal de exclusão da culpabilidade.

A doutrina alemã, talvez por deficiência do Código Penal tedesco, no que concerne à conceituação do estado de necessidade, construiu uma causa geral de exclusão da culpa com a inexigibilidade de outra conduta. E isto se deu principalmente depois do tribunal do Reich haver aplicado tal princípio a dois casos bastante conhecidos: um, foi o do empregado, cujo patrão mandou cavalgar um cavalo indócil, em plena via pública, sob pena de despedí-lo, resultando daí um atropelamento; o outro, o de uma parteira de uma região mineira, que foi levada a fazer inscrições falsas no Registro $\mathrm{Ci}$. vil. Como a direção das minas houvesse estabelecido que o operário, que viesse a ser pai, ficaria dispensado do trabalho, no dia do nascimento, os mineiros impuseram à profissional, com a ameaça de não mais se utilizarem de seus serviços, que, sempre que um nascimento ocorresse num domingo, o declarasse verificado em dia útil. Em ambos os casos o Reichsgericht julgou não ser possível exigir dos agentes comportamento distinto, isentando-os de culpa.

No Brasil, NELSON HUNGRIA mostra-se adversário da admissão dessa causa supra legal de exclusão da culpabilidade, sob o fundamento de que ela não se justifica perante os códigos mais recentes. Êstes não enseịariam o problema de suprir deficiências legislativas, como ocorre na Alemanha, com seu Código penal, velho de mais de meio século. "Os diplomas mais recentes" - afirma o eminente jurista - "procuram ir de encontro de tôdas as sugestões, no sentido de se obviarem os inconvenientes do sistema fechado da lei penal". Aliás, HUNGRIA não admite a analogia in honam partem, que teria que ser aplicada em tais casos. alegando que os preceitos sôbre causas excludentes constituem jus singulare, em relação aos preceitos sancionadores e, assim, não comportariam extensão, além dos casos taxativamente enumerados. (Comentários ao Código Penal, vol. I, pág. 76 e 77). 
De forma diversa pensa ANIBAL BRUNO, para quem a analogia só "é inadmissível se dela resulta definição de novos crimes ou de novas penas, ou, se, de qualquer modo, se agrava a situação do agente. Impede-a o princípio cardeal da legalidade dos crimes e das penas. Nas normas não incriminadoras - diz êle -, que escapam ao absoluto rigor dêsse princípio, e onde não há também que falar em excepcionalidade ou não excepcionalidade, porque essas normas não são exceções às normas incriminadoras, mas expressões, por si mesmas, de princípios gerais que se aplicam à matéria de que elas se ocupam, o processo de integração, por analogia, de possíveis lacunas, tem todo o cabimento. (ob. cit. t. 1, pág. 218). E, referindo-se à inexigibilidade de outra conduta, assevera o preciso professor do Recife, que "cabe admití-la com o caráter de causa geral de exclusão da culpabilidade em qualquer de suas formas, dolo ou culpa. Tal princípio no seu entender - "está realmente implícito no Código e pode aplicar-se por analogia, a casos semelhantes aos expressamente previstos no sistema. Na realidade são casos de verdadeiras lacunas na lei, que a analogia vem cobrir pela aplicação de um princípio latente no sistema legal. (ob. cit. t. 2, 484).

Parece que a razão está com o douto penalista pernambucano. Não há qualquer obstáculo à aplicação cautelosa do princípio à casos que, embora não se resolvam em situações de necessidade, revelem que não seria humanamente exigível um comportamento conforme ao Direito. Com isto poder-se-ia sanar as eventuais deficiências, que tôda a legislação, por mais perfeita, há de apresentar, diante da complexidade dos fenômenos humanos e sociais. A excludente poderia ter aplicação quer aos delitos culposos, cometidos em estados de fadiga ou de excitação, que dificultem ou tornem impossível a observância da diligência objetiva, quer aos crimes dolosos, mormente os de omissão, quando o cumprimento do dever seja inexigível, por acarretar danos de interêsses próprios, ao que, aliás, já se empresta relevância no delito de omissão de socorro.

De outra parte, a excepcional aplicação da inexigibilidade de outra conduta como causa supra legal de exclusão da culpa, sôbre atender a um ideal de justiça, viria tornar mais efetiva a regra fundamenral do nulla poena sine culpa, em que o nosso legislador diz se haver inspirado.

7. O princípio de que não há pena sem culpabilidade integra a consciência jurídico-penal moderna. Diz BELING que, no sistema do Direito Penal moderno, o dogma "ohne Schuld keine Strafe" representa a pedra fundamental, imóvel como uma rocha no meio do mar.

Lamentàvelmente contudo, o Direito Penal ainda não logrou livrar-se de todo da responsabilidade objetiva, sendo atual a observação de MEZGER de que o nulla poena sine culpa, é, por enquanto, um programa para o direito penal vigente e um princípio-meta para o direito futuro, cuja realização prática, sem exceções, se exige de 
modo imperioso pela consciência cultural de nossos dias (ob. cit. t2, pág. 21).

Na verdade, mesmo nos domínios da doutrina, revelam-se ainda desvios desta salutar e dignificante orientação. $E^{\prime}$ de nossos dias a doutrina da periculosidade, que em seu rigoroso significado abandona a responsabilidade pela culpabilidade. E isto, afirma RICARDO NUÑES, "como consequência inevitável de sua fórmula": não há delinquentes imputáveis e delinquentes não imputáveis; todos os autores de um delito respondem por êle pelo simples fato de viver em sociedade". (ob. cit., X!X). E' certo que, na prática, a culpabilidade não é de todo desprezada pelos adeptos desta corrente. Mesmo no projeto KRILENKO, o dolo e a culpa figuram com índices da periculosidade do indivíduo, influindo, desta maneira, na responsabilidade. Mas, deixando a culpabilidade de constituir pressuposto indeclinável da pena, é óbvio que esta concepção conduz à responsabilidade pelo resultado.

Também é atual a presença, na maioria das legislações, dos crimes qualificados pelo resultado, nos quais a pena é agravada pelo evento de maior gravidade, ainda que não querido, nem consentido pelo agente. Entendem uns que a imputação do resultado maior se faz pelo simples nexo de causalidade física entre êste e o resultado; sustentam outros que o evento qualificativo só pode ser atribuído ao agente quando causado culposamente, havendo assim, nestes delitos, uma forma de culpabilidade sui generis, resultante da conjugação do dolo e da culpa stricto sensu. Esta última orientação, que remonta à CARRARA e BINDING, parece preferível, pois como nota ASÚA, a fórmula de dolo no antecedente e culpa no consequente, permite-nos resolver muitos problemas e dar sentido lógico à expressão preter ou ultra-intencional.

Com base no nosso Código, pode ser construída a teoria do preterdolo, não obstante as opiniões em contrário de COSTA E SILVA (Código Penal, vol. 1, pág. 122), ANIBAL BRUNŐ (ob. cit. pág. 460), BASILEU GARCIA (ob. cit. pág. 269) e de ESTER DE FIGUEIREDO FERRAZ (Os delitos qualificados pelo resultado, págs. 134 e 135). Se o Código define, como formas dé culpabilidade, o dolo e a culpa e se consagra o princípio que, salvo os casos de crimes culposos, ninguém pode ser punido por fato, senão quando o cometa dolosamente, parece intutivo que, nos delitos qualificados pelo resultado, tem-se que invocar as duas formas de culpabilidade para cada um dos efeitos verificados. Esta, de resto, é a posição de NELSON HUNGRIA (ob. cit. vol. I, pág. 310), MAGALHÃES NORONHA (ob. cit., pág. 186) e JOSÉ FREDERICO MARQUES (Curso de Direito Penal, vol. 2, pág. 376) entre outros.

Como casos de responsabilidade objetiva apresentam-se em nossa legislação a punição dos crimes cometidos em estado de embriaguês completa, voluntária, ou culposa, a responsabilidade por contra- 
venções penais praticadas com simples voluntariedade, bem como a presunção de culpa, nos delitos de imprensa, para só citar as hipóteses mais características. JOSÉ FREDERICO MARQUES demonstra, com sua habitual maestria, que nos dois primeiros casos há um completo abandono do nulla poena sine culpa. (ob. cit. pág. 222).

No que toca a embriaguês, o art. 24 do Código expressamente estatui que, quando voluntária ou culposa, não exclui ela a responsabilidade penal.

Ora, sendo indiscutível que a embriaguês completa pode anular a capacidade intelectiva ou volitiva do agente, é manifesto que só por uma ficção jurídica, pode-se considerar, em tais casos, o agente como imputável, ocorrendo, em realidade, pura responsabilidade objetiva.

Costuma-se invocar, neste terreno, numa tentativa de conciliar a regra legal com o princípio da responsabilidade pela culpabilidade, a teoria da actio libera in causa segundo a qual, no correto conceito de BETTIOL, "o resultado produzido em estado de inimputabilidade deve ter sido previsto e querido pelo agente, e que છ̂ste se tenha pôsto em condição de incapacidade de entender ou de querer para praticar o crime, ou para preparar-se uma escusa. (ob. cit., pág. 271).

Ėsse princípio serve para justificar a punição na embriaguês préordenada, procurada precisamente para cometer o crime. Em tais hipóteses há, evidentemente, culpabilidade, pois que o agente, ao se embriagar, já procede com dolo. Costuma-se equiparar essas situações às de autoria mediata, em que alguém lança mão de um terceiro, inimputável, para a execução do crime. Como observa VON LISZT, "assim como nos podemos utilizar dos loucos e dos ébrios como instrumentos de nossos fins, porque nêles a faculdade de determinar-se por meio de representações, ainda que irregular, não é impossível, assim também podemos nos utilizar de nós mesmos, em estado de perturbação mental ou de embriaguês, para a execução de planos pré-concebidos". (ob. cit. vol. II, pág. 388).

Mas, quando a embriaguês não é preordenada, senão voluntária ou culposa, o princípio da actio libera in causa torna-se inaplicável. O agente embriagou-se por descuido ou pelo desejo de se embriagar, sem cogitar da prática de qualquer crime. Impossível, portanto, divisar dolo ou mesmo culpa em relação ao evento criminoso superveniente, no precedente estado de imputabilidade. A Exposição de Motivos do Código Penal, consoante MAGALHÃES NORONHA, dá extensão muito ampla à teoria da actio libera in causa, pois acha que a pessoa, embriagando-se, responde em virtude da ação livre em sua causa, porém não mostra o nexo psicológico (dolo ou culpa) com determinado crime. A imputação é a título genérico pelo crime que acaso venha a cometer (ob. cit. 229). Ora, faltando o dolo ou a culpa, manifesta é a objetividade da responsabilidade. 
Ademais, é necessário lembrar, com FREDERICO MARQUES, que, "se o Código considera responsável o indivíduo que comete um delito em estado de embriaguês, existe a imputabilidade ex vi legis; e isto não se harmoniza com a actio libera in causa, em que a imputabilidade existe no antecedente do ato e não por ocasião em que êste é praticado. Em relação a um preceito legal em que, per definitionem, a imputabilidade não é excluída nem diminuída, não se pode falar em actiones liberao in causa, como notou CRESPI, uma vez que nestas, também per definitionem, falta a imputabilidade no momento da prática do crime. (ob. cit. vol. 2, pág. 188).

Para a existência da contravenção penal, basta a ação ou omissão voluntária. Deve-se ter em conta o dolo e a culpa sòmente quando a lei faça depender de um ou de outro, qualquer efeito jurídico. $E^{\prime}$ o que está estatuído no art. $3 .^{\circ}$ da Lei de Contravenções. Penais.

Em relação às contravenções, portanto, o elemento moral esgota-se na simples voluntariedade, sendo dispensável prova de dolo ou culpa. E como a voluntáriedade do ato exaure-se com a liberdade e consciência em praticá-lo, independentemente da previsão, desejo ou aquiescência em causar uma lesão jurídica, é ineludível que, nas contravenções, a responsabilidade é objetiva.

$\mathrm{Na}$ Itália, tem-se procurado negar que nestas infrações exista responsabilidade objetiva. DE MARSICO sustenta que a contravenção exige um elemento subjetivo que pode ser indiferentemente o dolo ou a culpa, não bastando as simples voluntariedade do fato (apud. J. FREDERICO MARQUES, ob. cit. vol. 2, pág. 224). E VANNINI pensa que, ao contrário do que sucede com os crimes, onde tôda infração deve ser dolosa, sendo a culpa só excepcionalmente punida, nas contravenções é indiferente que o agente atue dolosa ou culposamente. Isto significa que não se faz tabula rasa do nexo subjetiva entre a vontade e o fato ilícito, para tão só exigir-se a voluntariedade da conduta. (La Contravvenzione dal Punto di Visła del suo Elemento Soggetivo, in Raccolta di Alcuni Scriti Minori, págs. 161, 163).

Êste ponto de vista é perfeitamente defensável ante a lei italiana, pois que esta estatui que; nas contravenções, cada um responde pela própria ação consciente e voluntária, seja essa dolosa ou culposa. O mesmo não ocorre, porém em face de nossa lei, que, em têrmos bem claros, diz bastar a ação ou omissão voluntária para a existência da infração.

Nos crimes de imprensa, de acôrdo com o art. 26 da respectiva lei (Lei 2.083 de 12 de novembro de 1953), quando o autor do fato incriminado não puder ser identificado, estiver ausente do país, ou não possuir idoneidade moral ou financeira, serão responsáveis sucessivamente pelo crime os diretores, os redatores, os distribuidores e os vendedores de tais publicações. $E^{\prime}$ ineludível que esta res.ponsabilidade sucessiva, contravém o princípio de que não há pena sem culpabilidade, constituindo a consagração do "qui in re illicita versatur 
etiam pro casu tenełur". Debalde procuram alguns, como ANTOLISEI, seguido por JOSÉ FREDERICO MARQUES, negar tal evidência, com a alegação que haveria nestes casos culpa in vigilando, por incumbir a tais pessoas verificar o que se publica nos órgãos que dirigem ou distribuem. Com isto, estabeler-se-ia apenas uma presunção absoluta de culpa, que em última análise reduz-se à responsabilidade objetiva. Depois, como justificaria esta presunção de culpa em sentido estrito a punição a título de crime doloso, a que estão sujeitas tais pessoas?

Tanto é verdade que a responsabilidade sucessiva nos delitos de imprensa não se harmoniza com os princípios da culpabilidade, que a legislação italiana, que adotava critério idêntico ao nosso, foi modificada por uma lei de 4 de março de 1.958, que veio a estabelecer: "salvo a responsabilidade do autor da publicação e fora dos casos de concurso, o diretor ou vice-diretor responsável, que deixa de exercer sôbre o conteúdo do periódico, por êle dirigido, o contrôle necessário a impedir, que, por meio da publicação, sejam cometidos crimes, é punido a título de culpa, se o crime vem a ser cometido, com a pena cominada a tal crime, diminuída no máximo de um têrço".

8. E' necessário que estas e outras hipóteses de responsabilidade objetiva, como a da já referida irrelevância do error juris, sejam de uma vez por tôdas banidas das legislações. Exige-o o estado atual do Direito Penal, que é "conceitualmente um Direito Penal da Culpabilidade, a ponto de MAX ERNEST MAYER, citado por A. BRUNO, já haver proclamado, que "tôda a dignidade do Direito Penal reside na reprovação da responsabilidade pelo resultado e no reconhecimento da responsabilidade pela culpabilidade". (ob. cit. pág. 408).

Auspiciosamente observa-se, entre nós, que a consciência jurídica brasileira já se apercebeu da necessidade de uma revisão de critérios, para excluir de nosso direito positivo os resíduos de primitivismo, que se encerram na responsabilidade sem culpa. A quase unanimidade dos estudiosos do Direito Penal insiste em erigir o nulla poena sine culpa num princípio central, efetivo e atuante.

Mesmo NELSON HUNGRIA, autor intelectual do Código vigente, com sua apurada sensibilidade, está hoje convencido, que certas normas "que a política criminal introduzira no direito penal legislado, "estão reclamando modificação. E, em conferência que recentemente pronunciou na Faculdade de Direito da Universidade da Guanabara. preconizou a equiparação do êrro de direito se êrro de fato, reputando contraditório e diverso tratamento que se lhes empresta, pois que, "se o justificável êrro de fato exclui a culpabilidade, lògicamente o mesmo efeito deve ser atribuido ao êrro de direito, desde que escusável. (Tribuna da Justiça, São Paulo, d. de 21 a 27 de novembro de 1961). 